\title{
Considerations regarding the osseointegration of endosseous dental implants
}

\author{
Consideraţii privind osteointegrarea implanturilor dentare endoosoase
}

Ion Pătrașcu, Bogdan Mihai Gălbinașu
Catedra de Tehnologia Protezelor şi Materiale Dentare, Facultatea de Medicină Dentară,
Universitatea de Medicină şi Farmacie „Carol Davila“, Bucureşti, România

\begin{abstract}
Implant osseointegration has not been accepted over time, considering that in fact the implant integration is performed only in the soft tissue of the host. For this reason, the implant has never been sufficiently integrated into the host tissue immediately after insertion. Experiments performed in Branemark laboratories in the early 1960s, with a new type of implant, which required a direct anchorage to bone tissue for clinical function, this anchorage was called osseointegration. It has been shown that it is possible to achieve direct osseointegration if the Branemark method is considered, which was published a few years later in the first clinical report.

The authors of this article come up with new contributions that validate the implant osseointegration process. Inside this article we present our methodology for evaluating the osseointegration of endosseous implants: ESEM (environmental scanning electron microscope) studies of the implant-bone tissue interface.
\end{abstract}

Keywords: dental implant, biocompatibility, environmental scanning electron microscope (ESEM), bone integration

\section{REZUMAT}

Osteointegrarea implantară nu a fost acceptată de-a lungul timpului, considerându-se că, de fapt, integrarea implantului se realizează doar în ţesutul moale al gazdei. Din acest motiv, implantul nu a fost niciodată integrat îndeajuns în ţesutul gazdei imediat după inserare. Experimentele efectuate în laboratoarele Branemark la începutul anilor 1960, cu un nou tip de implant, ce avea nevoie de o ancorare directă la ţesutul osos în scopul unei funcţionări clinice, a condus la denumirea de osteointegrare. S-a demonstrat că era posibil să se realizeze o osteointegrare directă dacă se lua în considerare metoda Branemark, ce a fost publicată câţiva ani mai târziu în primul raport clinic. Autorii acestui articol vin cu noi contribuţii care validează procesul de osteointegrare implantară. Pe parcursul acestui articol, prezentăm metodologia noastră de evaluare a osteointegrării implanturilor endoosoase: studii ESEM (environmental scanning electron microscope) de interfaţă implant - ţesut osos.

Cuvinte cheie: implant dentar, biocompatibilitate, ESEM, osteointegrare

\section{INTRODUCERE}

Un rol important pentru studiul prezentat pe parcursul acestui articol, dar şi pentru cercetările ulterioare îl au observaţiile unor autori consacraţi cu privire la factorii esenţiali ce determină osteointegrarea implanturilor dentare $[1,2]$.

Din nefericire, menţinerea şi restaurarea unui ligament parodontal propriu în jurul implantului dentar nu au fost încă descoperite. Cele mai încu- rajatoare cercetări au descris experimentele efectuate pe implanturi ortopedice ancorate printr-un tip particular de ţesut fibros, înalt diferenţiat, cu fibre aranjate într-un mod similar cu cele ale ligamentului parodontal. Oricum, această cercetare a fost de scurtă durată şi a rămas incert dacă este posibilă o ancorare asemănătoare ligamentului parodontal înalt diferenţiat în jurul implanturilor ce funcţionează clinic [3]. Pe de altă parte, se dovedeşte a fi 
esenţială apariţia unei zone periimplantare stabile care să se interpună atacului microbian din cavitatea bucală [4].

O analiză a răspunsului osos la majoritatea implanturilor folosite curent de stomatologi demonstrează că se pot întâmpla două incidente. Primul este respingerea tisulară, cu un răspuns inflamator acut sau cronic sau cu pierderea timpurie a implantului, iar cel de-al doilea, considerat frecvent ca un „răspuns de succes“, este producerea unei încapsulări fibroase neaderente, de grosime diferită, în jurul implantului. Unii autori insistă cu privire la obligativitatea dezvoltării unor astfel de răspunsuri tisulare fibroase [5], care sunt slab diferenţiate la implanturile metalice, indicând că astfel de implanturi sunt mai sigure imediat după inserţie şi că, progresiv, ar deveni mai „relaxate“. Aceste eşecuri sunt raportate la tipul de material foloşit, la localizarea implantului, la geometria lui [6,7], la stabilitatea fixării, iar la acestea se adaugă mulţi alţi factori.

Dacă inducerea formării osului în jurul unui astfel de implant ar fi clinic realizabilă, atunci s-ar putea prezice o metodă sigură de fixare sau ancorare şi ar avea loc „osteogeneza interfacială“ sau „osteointegrarea“ pe suprafaţa implanturilor metalice [8], fără orice fel de ţesut fibros interpus, verificate experimental în cadrul unor cercetări efectuate cu titan, oţel inoxidabil şi vitallium (aliaj de tip Co-Cr).

Per-Ingvar Branemark a descris termenul de „osteointegrare“ pentru a evidenţia contactul direct dintre os şi suprafaţa solicitată în cazul implanturilor dentare $[9,10]$. O caracteristică foarte interesantă a interfeţei osteointegrate este aceea că,

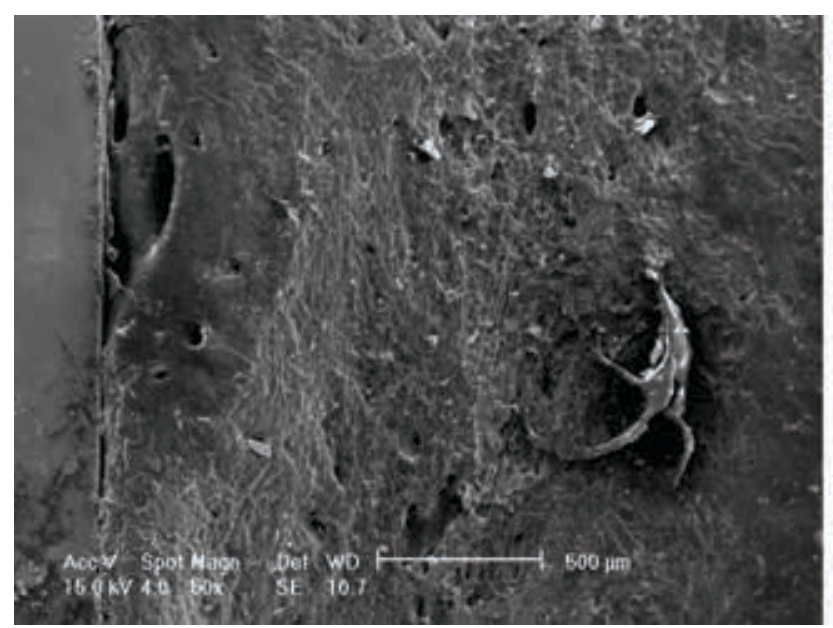

contrar interfeţelor tisulare fibroase slab diferenţiate, pare să stabilească o legătură mai putemică a implantului, odată cu trecerea timpului.

\section{SCOP}

În articolul de faţă, ne-am propus o analiză a osteointegrării implantare din punctul de vedere al biocompatibilităţii materialului implantar.

\section{MATERIAL ŞI METODĂ}

Cercetările efectuate au fost studii ESEM privind osteointegrarea implanturilor din biomateriale metalice $[11,12]$. Au fost analizate 4 probe diferite din punctul de vedere al materialului din care au fost confecţionate: titan pur (99\%), Ti6Al4V, aliaj inoxidabil austenitic $316 \mathrm{~L}$ şi Co-Cr-Mo. Forma sub care au fost pregătite pentru implantare a fost paralelipipedică. Studiile au fost efectuate pe animale de laborator, in vivo $[6,13,14]$. S-a practicat inserţia implanturilor la nivelul tibiei, transcortical, conform standardului ISO 10993. După 2 luni de la implantare, s-a practicat prelevarea probelor biologice reprezentate de fragmentele osoase ce conţineau implanturile. Acestea au fost supuse investigaţiilor de microscopie electronică cu ajutorul cărora au fost efectuate analize pe suprafaţă de tip mapping [15], prin care s-au identificat elementele chimice şi s-a urmărit distribuţia acestora la interfaţa implant - ţesut osos.

\section{REZULTATE}

Prima probă din titan pur (Ti 99\%) a fost supusă analizei EDAX la interfaţa implant - ţesut osos.

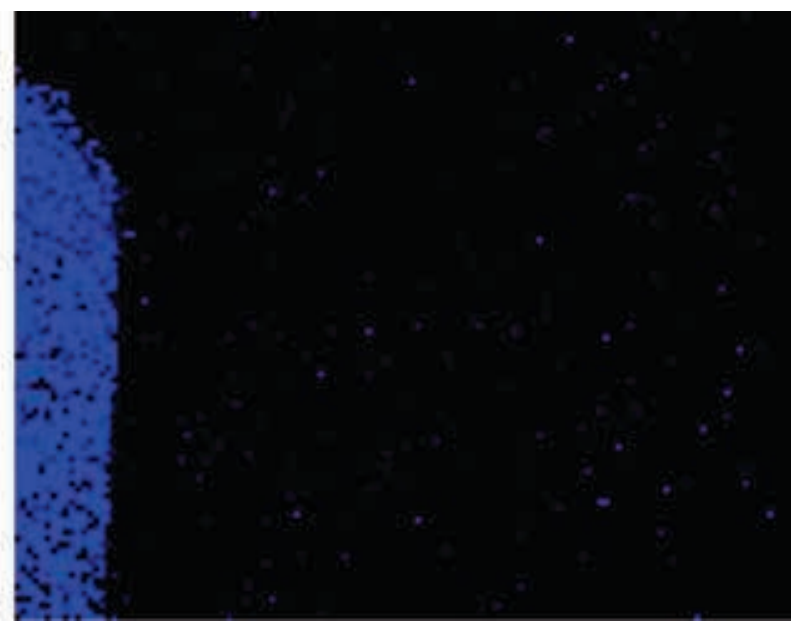


S-a identificat migrarea atomilor de titan de la suprafaţa implantului (figura 1). Deşi se consideră că titanul pur are gradul cel mai ridicat de bioinerţie, reacţiile redox cu lichidul fiziologic, deşi de mică intensitate, se produc la nivelul interfeței acestuia.

La nivelul celei de-a doua probe, confecţionată din aliaj tip Ti6Al4V, s-a constatat, prin analiză EDAX pe suprafaţă, o difuzie crescută a vanadiului şi, în proporţie mai redusă, a aluminiului în ţesuturile adiacente. Dacă facem o comparaţie a rezultatelor obţinute după analiza EDAX a celor 2 probe, se observă o instabilitate chimică a Ti din aliajul Ti6Al4V, cu o difuzie a oxizilor de titan în ţesutul osos periimplantar mai ridicată. Acest aspect se consideră a fi consecinţa unor reacţii chimice la interfaţă mult mai intense (figura 2).

Proba a treia a fost obţinută din aliaj inoxidabil austenitic 316L. Dupa prelevarea probei şi analiza EDAX pe interfaţă (figura 3), s-au obţinut rezultate care evidenţiază migrarea mai multor elemente compoziţionale. Elementul care a difuzat cel mai puţin a fost cromul, urmat de nichel. S-a constatat că, dintre toate elementele compoziţionale, cromul a avut cea mai mare stabilitate. Elementul cu cel mai ridicat grad de migraţie a fost fierul.
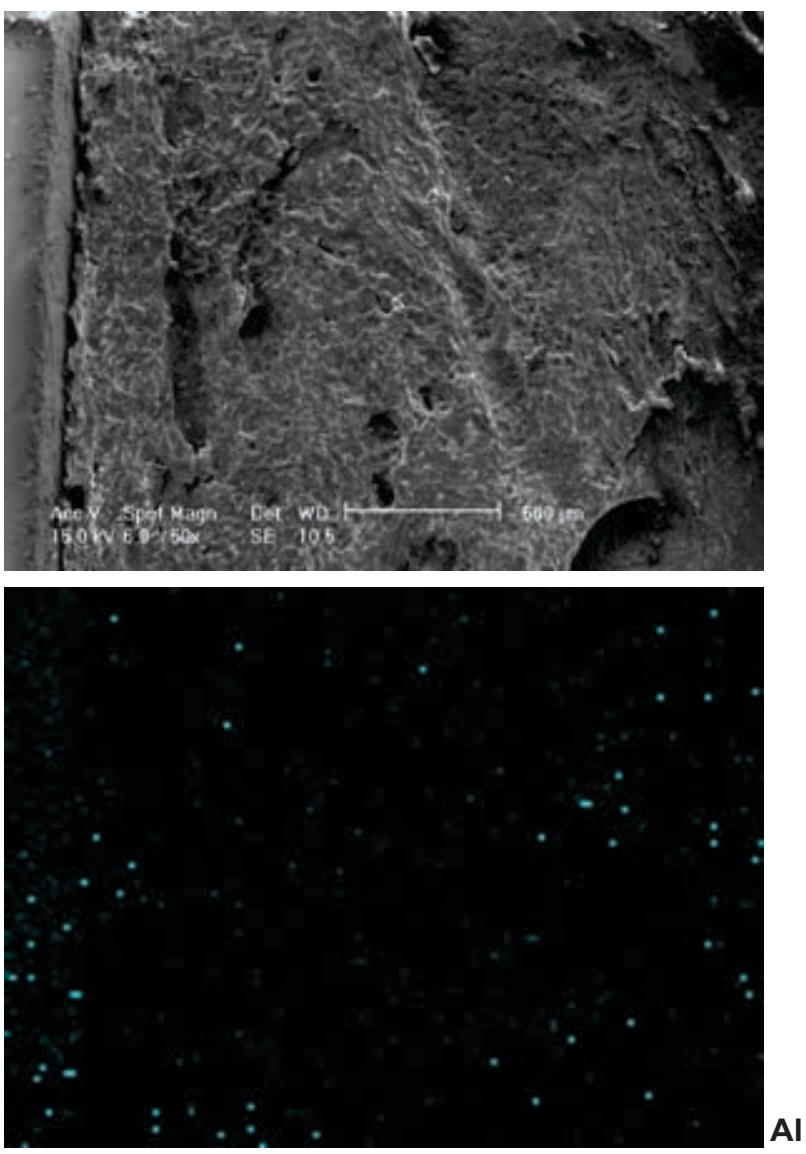

A patra probă luată în studiu a fost reprezentată de un aliaj Co-Cr-Mo. S-a efectuat şi pentru aceasta o analiză EDAX pe suprafaţa interfeţei implant ţesut osos periimplantar (figura 4). Analiza stabilităţii chimice a aliajului folosit pentru implant a evidenţiat o difuzie crescută a molibdenului, cobaltul şi cromul fiind mai stabile ca elemente compoziţionale. Această migrare accentuată a molibdenului sugerează o prezenţă intensă a reacţiilor chimice de oxido-reducere.

\section{DISCUȚII}

Indiferent de biomaterialul metalic din care a fost confecţionat implantul, s-a constatat o migrare a elementelor acestuia, dar şi invers [16,17]. Cel mai stabil chimic în mediul biologic a fost implantul din titan pur. Implantul din Ti6Al4V a pierdut în mediul biologic $\mathrm{V}$, pierderile de aluminiu fiind corelate cu cele de Ti. Implantul din Co-Cr-Mo a generat o difuzie ridicată a cobaltului şi molibdenului. Implantul din oţel inoxidabil a determinat difuzie în principal a fierului şi secundar a nichelului, cromul fiind mult mai stabil.
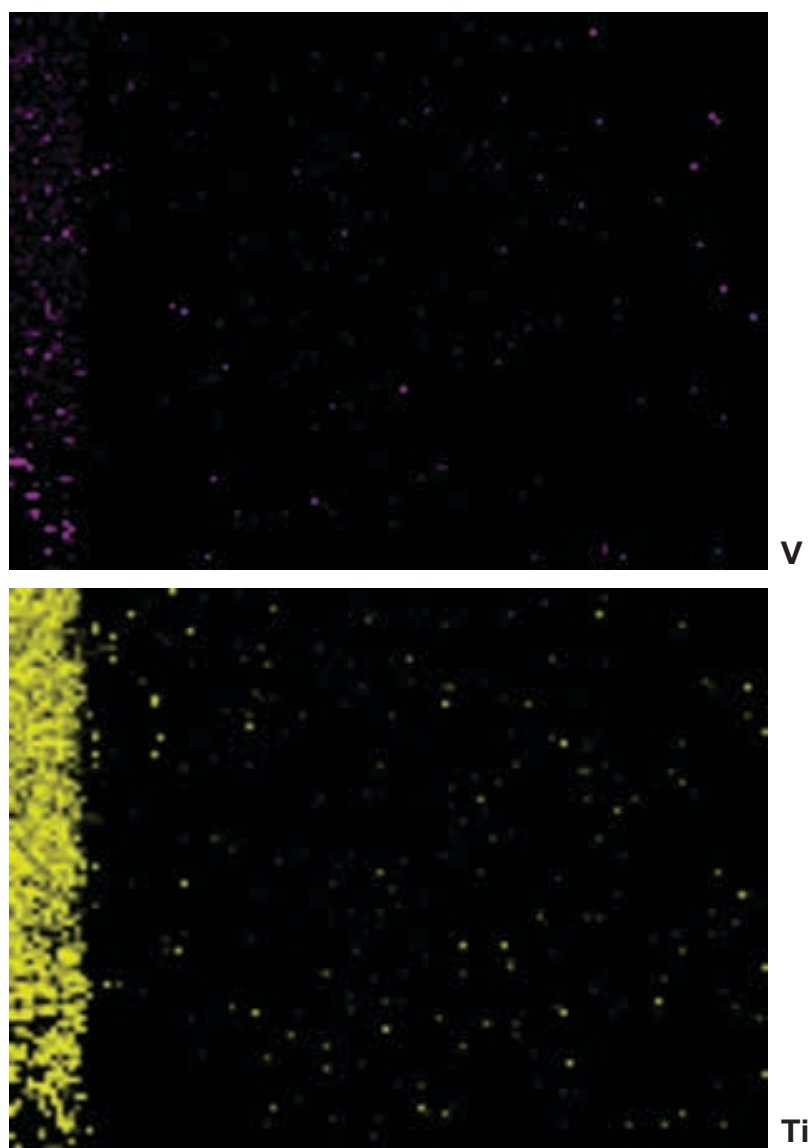

FIGURA 2. Difuzia elementelor din aliajul Ti6Al4V 

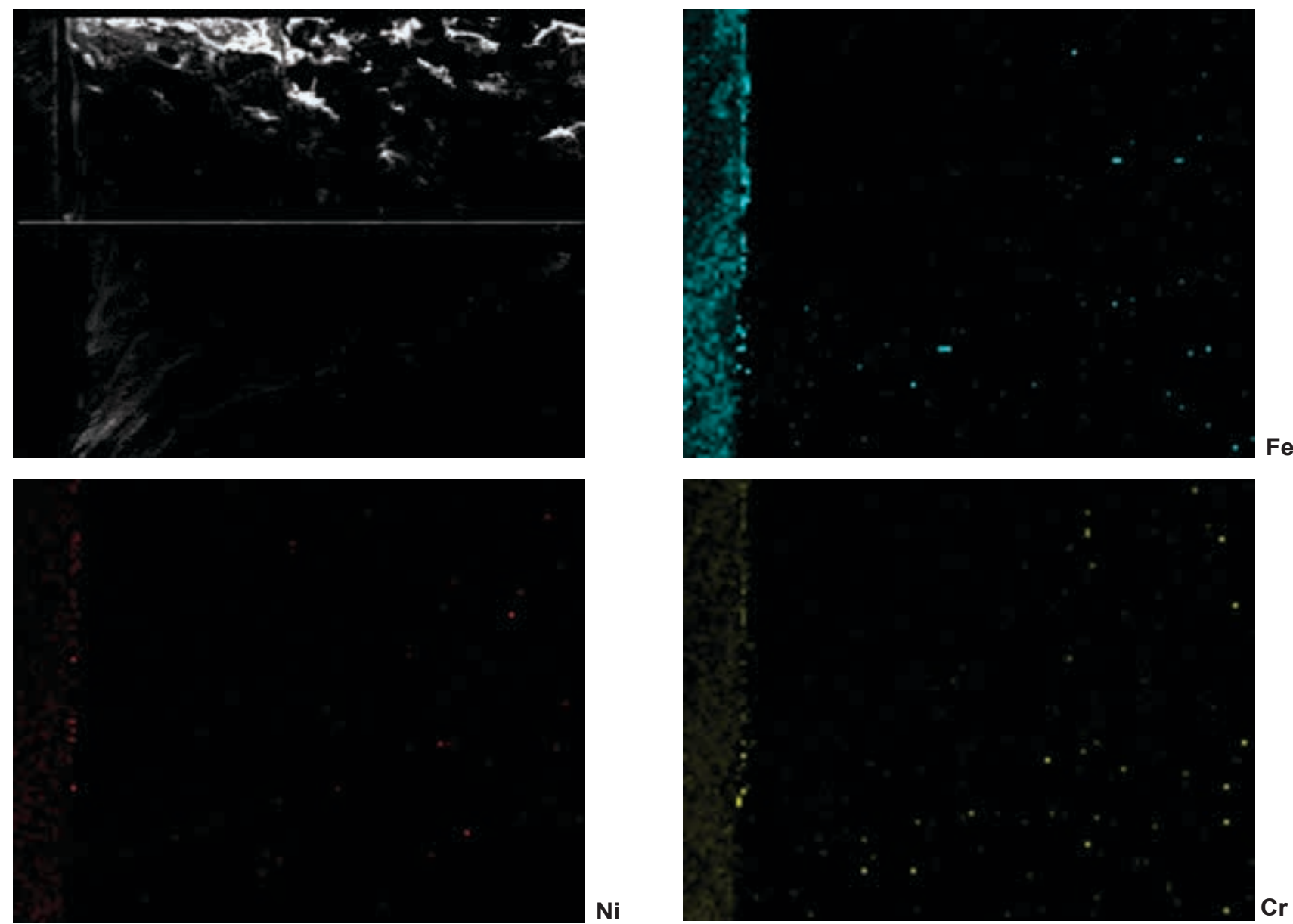

FIGURA 3. Analiza EDAX a aliajului $316 L$
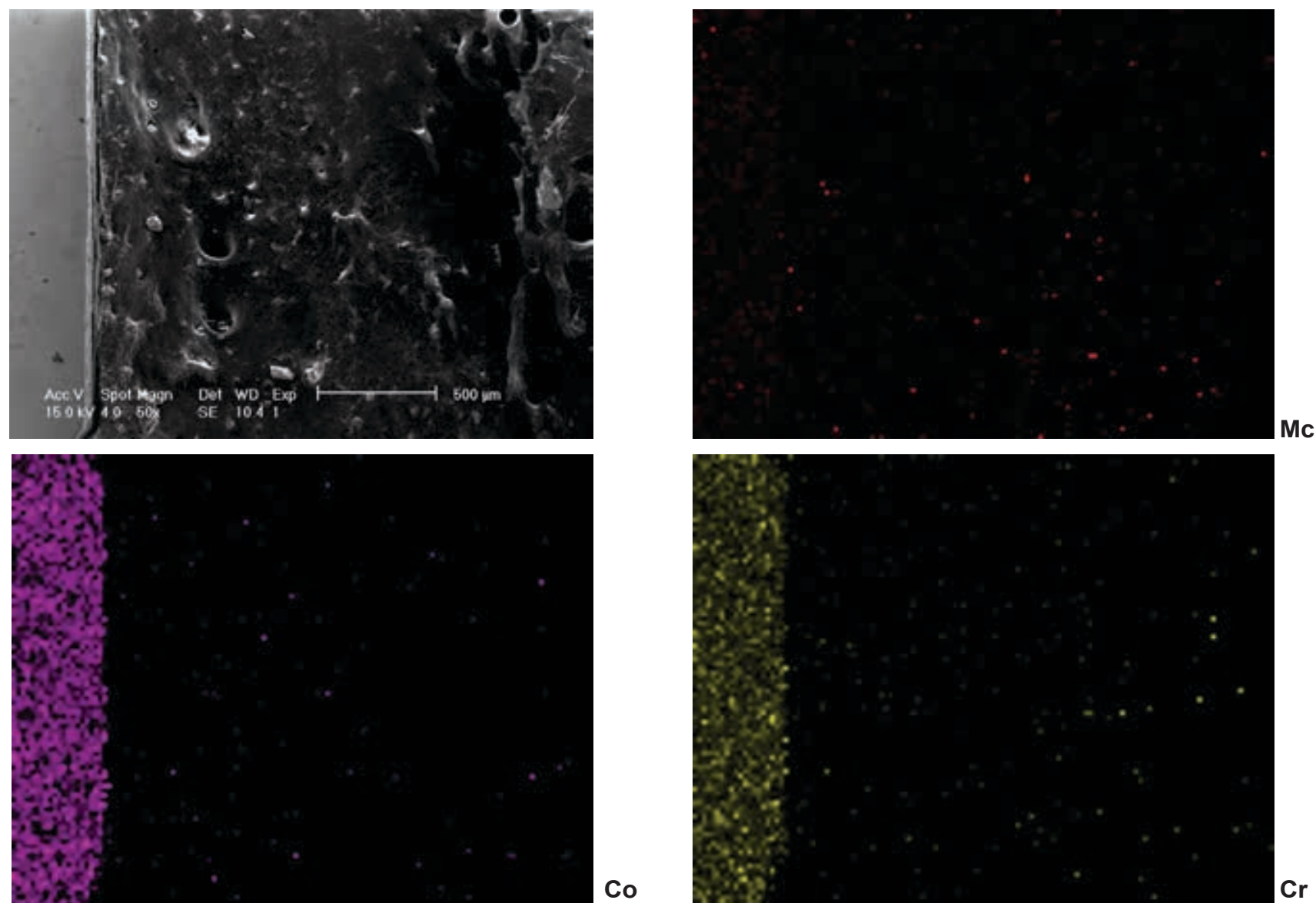
Ţesutul osos de neoformaţie a fost intens mineralizat în cazul implantului din Ti pur, mai redus mineralizat în cazul implantului din TiAl64V, slab mineralizat pentru implantul din Co-Cr-Mo şi aproape deloc mineralizat pentru implantul din aliaj inoxidabil.

Analiza de tip mapping a evidenţiat interacţiunea chimică intensă între materialul implantat şi mediul de implantare, indiferent de tipul biomaterialului metalic evaluat: titan pur (99\%), Ti6Al4V, oţel inoxidabil austenitic tip 316L, aliaj Co-CrMo. Pentru niciuna dintre probe nu au fost observate procese de osteoliză periimplantară, ceea ce dovedeşte existenţa unei interacţiuni favorabile între biomaterialul implantat şi structura biologică (ţesutul osos).

Gradul de dezvoltare şi mineralizare a matricei organice periimplantare s-a aflat în strânsă corelaţie cu modificările biochimice de la interfaţă.

Conflict of interest: none declared

Financial support: none declared

\section{BIBLIOGRAFIE}

1. Zarb CA, Albrektsson T. Nature of implant attachments. In: Branemark P-I, Zarb C, Albrektsson T (eds.). Tissue-integrated prostheses osseointegration in clinical dentistry. Chicago: Quintessence Publishing Co., 1985:88-98.

2. Albrektsson T, Zarb G, Worthington P, Eriksson AR. The long-term efficacy of currently used dental implants: a review and proposed criteria of success. Int J Oral Maxillofac Implants. 1986 Summer;1(1):11-25.

3. Zarb GA, Albrektsson T. Osseointegration: a requiem for periodontal ligament? Int J Periodontal Restor Dent. 1991;11:88-91.

4. Linkevicius T, Apse P. Biologic width around implants. An evidencebased review. Stomatologija. 2008;10(1):27-35.

5. Shemtov-Yona K, Rittel D. Random spectrum loading of dental implants: An alternative approach to functional performance assessment. J Mech Behav Biomed Mater. 2016 Sep;62:1-9.

6. Calvo-Guirado JL, Satorres M, Negri B, Ramirez-Fernandez P, Maté-Sánchez de Val JE, Delgado-Ruiz R, Gomez-Moreno G, Abboud M, Romanos GE. Biomechanical and histological evaluation of four different titanium implant surface modifications: an experimental study in the rabbit tibia. Clin Oral Investig. 2014;18(5):1495-505.

7. Berglundh T, Abrahamsson I, Welander M, Lang NP, Lindhe J. Morphogenesis of the peri-implant mucosa: an experimental study in dogs. Clin Oral Implants Res. 2007 Feb;18(1):1-8.

8. Kini $U$ et al. Physiology of Bone Formation, Remodeling and Metabolism. In: Fogelman I, Gnanasegaran G, van der Wall H. Radionuclide and Hybrid Bone Imaging. Springer-Verlag, 2012:29-57.

9. Brånemark $\mathrm{PI}$, Hansson $\mathrm{BO}$, Adell R, Breine U, Lindström J, Hallén $\mathrm{O}$, Ohman A. Osseointegrated implants in the treatment of the edentulous jaw. Experience from a 10-year period. Scand J Plast Reconstr Surg Suppl. 1977;16:1-132.

10. Brånemark PI. Osseointegration and its experimental background. J Prosthet Dent. 1983 Sep;50(3):399-410.

\section{CONCLUZII}

Studiile experimentale in vivo, privind interacţiunile care au loc la interfaţa biomaterial - țesut osos, au permis formularea unor concluzii elocvente. Studiile privind osteointegrarea sunt foarte importante pentru dezvoltarea perpetuă a terapiilor implantare. Stomatologia modernă e în strânsă corelaţie cu utilizarea implanturilor dentare şi, în consecinţă, e nevoie de o perfectare continuă a acestora. Se impun atât studii cu privire la materialele, forma şi structura implanturilor, cât şi studii de interfaţă, ce trebuie să definească interacţiunea cu ţesuturile dure şi moi. Cercetările în domeniu reprezintă o necesitate, iar gradul lor de complexitate trebuie să cunoască o creştere exponenţială.

11. Shah FA, Ruscsák K, Palmquist A. 50 years of scanning electron microscopy of bone-a comprehensive overview of the important discoveries made and insights gained into bone material properties in health, disease, and taphonomy. Bone Res. 2019 May 22;7:15.

12. Gandolfi MG, Zamparini F, lezzi G, Degidi M, Botticelli D, Piattelli A, Prati C. Microchemical and Micromorphologic ESEM-EDX Analysis of Bone Mineralization at the Thread Interface in Human Dental Implants Retrieved for Mechanical Complications After 2 Months to 17 Years. Int J Periodontics Restorative Dent. 2018 May/ Jun;38(3):431-441.

13. Novaes AB Jr, Ramos UD, Scombatti de Souza SL, Muglia VA, Gonçalves de Almeida AL, de Moraes Rego Mandetta C. The Effect of Antimicrobial Photodynamic Therapy in the Osseointegration of Immediately Placed Implants in Sites with Ligature-Induced Periodontitis in Dogs. Int J Periodontics Restorative Dent. 2020 Nov/ Dec;40(6):917-923.

14. Berglundh T, Abrahamsson I, Welander M, Lang NP, Lindhe J. Morphogenesis of the peri-implant mucosa: an experimental study in dogs. Clin Oral Implants Res. 2007 Feb;18(1):1-8.

15. Prati C, Zamparini F, Botticelli D, Ferri M, Yonezawa D, Piattelli A, Gandolfi MG. The Use of ESEM-EDX as an Innovative Tool to Analyze the Mineral Structure of Peri-Implant Human Bone. Materials (Basel). 2020 Apr 3;13(7):1671.

16. Biguetti CC, Cavalla F, Silveira EV, Tabanez AP, Francisconi CF, Taga R, Campanelli AP, Trombone APF, Rodrigues DC, Garlet GP. HGMB1 and RAGE as Essential Components of Ti Osseointegration Process in Mice. Front Immunol. 2019 Apr 5;10:709.

17. Biguetti CC, Cavalla F, Silveira EM, Fonseca AC, Vieira AE, Tabanez AP, Rodrigues DC, Trombone APF, Garlet GP. Oral implant osseointegration model in C57BI/6 mice: microtomographic, histological, histomorphometric and molecular characterization. J Appl Oral Sci. 2018 Jun 11;26:e20170601. 